\title{
Evaluasi Pelaksanaan Cetak Sawah di Provinsi Kalimantan Barat
}

\section{Evaluation of Paddy Field Printing Implementation in West Kalimantan Province}

\section{Valeriana Darwis ${ }^{*}$}

${ }^{1}$ Pusat Sosial Ekonomi dan Kebijakan Pertanian Jln. Tentara Pelajar No. 3 B Bogor

*E-mail : valicfurca@gmail.com

\begin{abstract}
Food, especially rice, is a basic human ingredient whose needs increase following the population growth. On the other hand the availability of rice has decreased following the land conversion rate. To overcome land conversion and to increase national rice production, the government made policy of paddy expansion / printing. In 2016 this activity is implemented in 27 provinces and has been printed new fields of 129,096 ha. One of the provinces that get the rice field printing program is West Kalimantan Province. From the results of the evaluation, the location of the new paddy fields is in accordance with the objectives of the program, namely: rice fields have been formed, farmers who work around the location of land and water sources for cultivation is also available. From the paddy field experience of 2016, the improvements required for next year's paddy fields include: (i) preferably planning (SI\&D) in advance a year is made than the implementation and (ii) additional paddy rice costs, as the cost of expensive tool mobilization and social costs and (iii) a binding rule in the form of sanctions for the farmer who converted the new fields. As for improving the required crop index: water management; subsidizing inputs (seeds, fertilizers, lime, farming tools and cultivation training.
\end{abstract}

Keywords : Constraints, Solutions and paddy field printing

Disubmit : 2 Mei 2018 ; Diterima: 3 Maret 2019 ; Disetujui : 10 April 2019

\section{PENDAHULUAN}

Masalah pangan terutama beras akan selalu menjadi isu strategis, karena menyangkut kebutuhan pokok masyarakat yang memiliki kecenderungan meningkat terus mengikuti pertambahan jumlah penduduk. Selain strategis beras juga merupakan komoditas politik yang persediaannya tidak boleh berkurang, karena akan membuat kegaduhan baik dari sisi ekonomi maupuan sosial. Pentingnya beras juga direpresentasikan dalam kebijakan pemerintah Jokowi-JK dengan memasukkan ketahanan pangan dalam salah satu nawacita, terutama dalam hal: pangan yang cukup untuk masyarakat, menurunkan angka kemiskinan, dan mensejahterakan petani. Pemerintah Indonesia, khususnya Kementerian Pertanian bercita-cita ingin mewujudkan negara kita sebagai lumbung pangan dunia pada tahun 2045.

Menurut Menteri Pertanian (Sulaiman. A .A, 2017), dalam kata sambutan pada pembukaan seminar nasional di Universitas Galuh menyatakan harapan menjadi lumbung pangan bisa terlaksana apabila beberapa permasalahan di sektor pertanian bisa teratasi dan permasalahan tersebut antara lain : (1) Status dan luas kepemilikan lahan petani yang sempit, lebih dari 9,55 juta KK petani hanya memiliki lahan kurang dari 0,5 ha, (2) Ketersediaan infrastruktur, sarana prasarana, lahan, air bersih, dan energi yang belum memadai, (3) Keterbatasan akses petani terhadap permodalan dan masih tingginya suku bunga perbankan, (4) Lemahnya kapasitas dan kelembagaan petani dan penyuluh pertanian, (5) Kemampuan manajerial petani dalam agribisnis yang masih terbatas, (6) serta fenomena perubahan iklim global yang makin ekstrim, 
bencana alam, meningkatnya degradasi sumberdaya pertanian termasuk sumberdaya genetik dan meningkatnya kerusakan lingkungan.

Untuk mengatasi permasalahan diatas, Kementerian Pertanian menciptakan berbagai program terobosan kebijakan pembangunan pertanian melalui optimalisasi lahan, penambahan luas tanam, perbaikan infrastruktur dan penyediaan bantuan sarana usaha tani, serta penataan sumber daya manusia (SDM). Khusus tanaman pangan nasional untuk tahun 2015-2019, Kementerian Pertanian lebih memfokuskan kebijakan pembangunan pada upaya peningkatan produksi padi, jagung, dan kedelai secara nasional dalam tiga tahun kedepan (UPSUS 2015-2017). Political will yang diperlihatkan dalam kebijakan ini didasarkan atas keinginan menekan bahan pangan impor dan semakin mendorong pasokan pangan dari dalam negeri.

Kebutuhan pangan terutama beras, sampai sekarang pasokannya paling banyak berasal dari Pulau Jawa. Menurut Irawan, (2005) selama tahun 1985-2005 sekitar 55-62 persen produksi padi nasional dihasilkan di Pulau Jawa, tetapi pada tahun 2013 kontribusi produksi padi di Pulau Jawa menurun menjadi 52.16 persen (BPS.2014). Lebih lanjut Irawan, dkk (2013) mengemukakan beberapa penyebab penurunan produksi di Jawa,yaitu: (1) jaringan irigasi di Pulau Jawa banyak yang tidak terpelihara, (2) terjadinya konversi lahan sawah ke penggunaan non pertanian, (3) pencetakan sawah baru di Jawa sulit diwujudkan akibat keterbatasan sumberdaya lahan, (4) peningkatan produktivitas padi sawah sulit diwujudkan akibat adanya fenomena kelelahan lahan yang menyebabkan respon produktivitas padi terhadap penggunaan input semakin kecil, dan (5) adanya kebijakan nasional jangka panjang yang tidak kondusif bagi keberlanjutan lahan sawah di Pulau Jawa.

Selain masalah persaingan dalam penggunaan air, banjir dan longsor, alih fungsi lahan dari sektor pertanian ke non pertanian menjadi penyebab berkurangnya penyediaan beras. Semakin tinggi tingkat alih fungsi lahan semakin menurun produksi pangan (Abdurahman, dkk, 2008). Ketersediaan lahan menurut data BPS menunjukkan lahan baku pertanian berdasarkan perhitungan tahun 2002 seluas 7,75 juta hektar. Dengan laju alih fungsi lahan 110.000 hektar setiap tahun, Kontak Tani Nelayan Andalan (KTNA) menghitung tahun 2011 sisa luasan lahan baku pertanian hanya 6,76 juta hektar (Kompas, 2012), Hasil kajian KPK alih fungsi lahan berlangsung secara masif dengan pengurangan lahan pertanian berkisar antara 50-60 ribu hektar per tahun atau sama dengan pengurangan produksi padi sebanyak 300.000 ton (Suparman.F, 2016).

Menurut Sumaryanto, dkk (2005), alih fungsi lahan secara nasional mencapai 1,628 juta ha selama kurun waktu 1981-1999 dan lahan sawah yang terkonversi tersebut mulanya beririgasi teknis atau setengah teknis dengan produktivitas tinggi. Menurut data Kementerian Pertanian menunjukan laju alih fungsi lahan pertanian per tahun 100.000 ha, tetapi cetak sawah baru per tahun kurang dari 50.000 hektar (Kompas, 2012) Prediksi yang dilakukan oleh Agus et al., (2006) menyebutkan bahwa apabila konversi lahan sawah terjadi pada laju 100,000 per tahun maka untuk mempertahankan swasembada beras, pencetakan lahan sawah baru harus tidak kurang dari 150,000 ha tahun. Hal ini akan mengancam ketahanan pangan nasional. Untuk itulah Kementerian Pertanian melalui Direktorat Jenderal Prasarana dan Sarana Pertanian membuat kegiatan cetak sawah. Pencetakan sawah dilakukan untuk menambah luas lahan sawah yang dapat ditanami padi di berbagai wilayah, mengoptimalkan pemanfaatan lahan, serta membuka peluang meningkatkan pendapatan petani dan mengembangkan ekonomi wilayah setempat. Hal yang senada juga diungkapkan oleh Mulyani dan Agus, (2006), pencetakan sawah merupakan salah satu usaha dalam mewujudkan ketahanan pangan selain usaha lainnya seperti pengendalian konversi lahan pertanian dan intensifikasi sistem pertanian dengan menerapkan teknologi yang dapat meningkatkan produktivitas dan sekaligus mempertahankan kualitas lingkungan.

Dengan uraian di atas maka tulisan ini bertujuan : (i) mengetahui pelaksanaan dan permasalahan yang dirasakan oleh pelaksana kegiatan cetak sawah tahun anggaran 2016 di Provinsi Kalimantan Barat ; serta (ii) saran perbaikan pelaksanaan cetak sawah untuk tahun anggaran berikutnya. 


\section{METODE PENELITIAN}

Tulisan ini merupakan bagian dari hasil evaluasi kinerja pelaksanaan kegiatan perluasan sawah tahun 2016 yang dilaksanakan oleh Direktorat Jenderal Prasarana dan Sarana Pertanian yang bekerjasama dengan Pusat Sosial Ekonomi dan Kebijakan Pertanian Kementerian Pertanian. Lokasi yang dievaluasi dipilih secara purposif dengan pertimbangan mewakili pulau di Indonesia. Dengan kriteria tersebut provinsi yang terpilih antara lain : Sumatera Selatan dan Lampung untuk Pulau Sumatera ; Kalimantan Barat dan Kalimantan Tengah untuk Pulau Kalimantan; Sulawesi Tenggara dan Sulawesi Tengah untuk Pulau Sulawesi dan Nusa Tenggara Timur untuk kawasan Pulau Jawa, NTB dan NTT. Pada setiap provinsi dipilih 2 atau 3 kabupaten yang menjadi target pencetakan sawah. Survai ke provinsi dan kabupaten dilakukan pada bulan Maret 2017. Dalam tulisan ini lebih memfokuskan pelaksanaan kegiatan cetak sawah di Provinsi Kalimantan Barat dengan kabupaten terpilih adalah Sanggau dan Landak.

Data-data yang dipergunakan terdiri data primer dan sekunder. Data sekunder dikumpulkan dari : Direktorat Sarana dan Prasarana Kementan, Dinas Pertanian Provinsi Kalimantan Barat, Kabupaten Sanggau dan Landak, serta dari pelaksana kegiatan. Data Primer dikumpulkan dari hasil wawancara langsung mempergunakan pertanyaan terstruktur (kuesioner) terhadap pelaksana kegiatan seperti : konsultan yang membuat Survai Investasi dan Design (SI \& D); IPL/TNI, pengusaha yang mencetak sawah, dan 6 kelompok tani penerima manfaat perkabupaten dan masing-masing kelompok tani diwakili oleh $2 \mathrm{~s} / \mathrm{d} 3$ orang. Data yang terkumpul selanjutnya dipilah dan diorganisasikan untuk menghasilkan tabel yang dianalisis secara deskriptif.

\section{HASIL DAN PEMBAHASAN}

Perluasan sawah adalah suatu usaha penambahan luas baku lahan sawah pada berbagai tipologi lahan yang belum pernah diusahakan untuk pertanian dengan sistem sawah. Sementara defenisi sawah adalah : lahan usahatani yang secara spesifik permukaan tanahnya rata, dibatasi oleh pematang, sehingga dapat ditanami padi dengan sistem genangan dan palawija atau tanaman lainnya.

Perluasan sawah pada tahun anggaran 2016 telah dilaksanakan di 161 kabupaten pada 27 provinsi (Tabel 1). Lahan yang berhasil dicetak seluas 129.096 hektar dari target yang direncanakan seluas 132.167 hektar atau 2,3 persen tidak sesuai dengan target. Luasan cetak sawah yang paling luas terletak di provinsi Kalimantan Barat dan Kalimantan Tengah, yaitu dengan kontribusi masing-masing terhadap total sebesar $12,8 \%$ atau seluas 16.905 ha dan $12,5 \%$ atau seluas 16.550 hektar. Dari luasan sawah yang sudah dicetak 82.128 hektar sudah berhasil ditanami padi, sisanya sebesar 36,4 persen (46.968 ha) belum ditanami padi.

Provinsi Kalimantan Barat selain terluas cetak sawahnya, juga termasuk provinsi yang 100 persen merealisasikan cetak sawah. Tahun 2016 lokasi cetak sawah di Kalimantan Barat ada di 8 kabupaten. Kabupaten yang paling luas adalah Kabupaten Sanggau, yaitu seluas 4.800 hektar (Tabel 2). Dilanjutkan di Kabupaten Landak yang merupakan kabupaten kedua terluas cetak sawahnya, yaitu seluas 4.000 hektar. Dari total realisasi sawah yang dicetak 12.293 hektar (73\%) sudah ditanami dan sisanya seluas 4.612 hektar belum ditanami. Dari hasil diskusi dengan Dinas Pertanian Provinsi Kalimantan Barat ada beberapa permasalahan kenapa tidak semua lahan ditanami langsung dan permasalahan tersebut diantaranya adalah : (i) saat tanam waktunya berhimpitan dengan kegiatan adat, (ii) bantuan saprodi terlambat datang dan ada juga kelompok yang tidak menerima saprodi, (iii) air tidak mencukupi, dan (iv) waktunya bersamaan dengan jadwal petani mengerjakan ladang.

Hirarki Pelaksanaan. Pelaksanaan perluasan sawah tahun 2016 merupakan kegiatan kerjasama antara Menteri Pertanian RI sebagai pemegang dana dengan Kepala Staff Angkatan Darat sebagai pelaksana kegiatan (gambar 1). 
Tabel 1. Realisasi Fisik Kegiatan Cetak Sawah 2016

\begin{tabular}{|c|c|c|c|c|c|}
\hline No & Provinsi & Target & Realisasi fisik & Luas tanam & Belum tanam \\
\hline 1 & Kalimantan Barat & 16.905 & 16.905 & 11.736 & 5.169 \\
\hline 2 & Kalimantan Tengah & 16.550 & 16.550 & 7.899 & 8.651 \\
\hline 3 & Lampung & 11.995 & 11.875 & 10.335 & 1.540 \\
\hline 4 & Nusa Tenggara Barat & 11.537 & 11.537 & 3.474 & 8.063 \\
\hline 5 & Sumatera Selatan & 11.475 & 11.475 & 8.833 & 2.642 \\
\hline 6 & Sulawesi Selatan & 9.940 & 9.940 & 9.558 & 382 \\
\hline 7 & Kepulauan Babel & 7.130 & 7.130 & 3.694 & 3.436 \\
\hline 8 & Sulawesi Tenggara & 6.000 & 6.000 & 2.911 & 3.089 \\
\hline 9 & Sulawesi Tengah & 4.962 & 4.962 & 3.344 & 1.618 \\
\hline 10 & Sulawesi Barat & 4.260 & 4.260 & 1.805 & 2.456 \\
\hline 11 & Papua & 4.150 & 4.150 & 2.502 & 1.648 \\
\hline 12 & Kalimantan Selatan & 3.236 & 3.000 & 2.642 & 358 \\
\hline 13 & Sulawesi Utara & 2.855 & 2.855 & 2.731 & 124 \\
\hline 14 & Jambi & 2.580 & 2.580 & 2.140 & 440 \\
\hline 15 & Aceh & 2.500 & 2.450 & 1.341 & 1.109 \\
\hline 16 & Papua Barat & 2.272 & 2.372 & 1.892 & 481 \\
\hline 17 & Gorontalo & 2.090 & 2.090 & 303 & 1.787 \\
\hline 18 & Nusa Tenggara Timur & 2.864 & 1.722 & 585 & 1.137 \\
\hline 19 & Maluku & 1.525 & 1.610 & 867 & 744 \\
\hline 20 & Maluku Utara & 1.500 & 1.460 & 574 & 886 \\
\hline 21 & Kalimantan Timur & 1.184 & 1.162 & 634 & 528 \\
\hline 22 & Riau & 950 & 813 & 616 & 197 \\
\hline 23 & Kalimantan Utara & 922 & 726 & 610 & 116 \\
\hline 24 & Sumatera Barat & 608 & 601 & 371 & 230 \\
\hline 25 & Jawa Barat & 500 & 500 & 500 & 0 \\
\hline 26 & Kepulauan Riau & 1.537 & 232 & 125 & 107 \\
\hline 27 & Bengkulu & 140 & 140 & 109 & 31 \\
\hline & Total Jumlah & 132.167 & 129.096 & 82.128 & 46.968 \\
\hline
\end{tabular}

Sumber :. (Dirjen Sarana dan Prasarana, 2017)

Tabel 2. Target, Realisasi dan Posisi Tanam. 2016

\begin{tabular}{llrrrr}
\hline No & Kabupaten & Target & Realisasi & \multicolumn{2}{c}{ Posisi Tanam (ha) } \\
\cline { 5 - 6 } & (ha) & 4.000 & 4.000 & Sudah & Belum \\
\hline 1 & Landak & 1.140 & 1.140 & 3.177 & 824 \\
2 & Sambas & 1.400 & 1.400 & 1.140 & 0 \\
3 & Ketapang & 4.800 & 4.800 & 784 & 616 \\
4 & Sanggau & 550 & 550 & 4.428 & 372 \\
5 & Sekadau & 1.515 & 1.515 & 500 & 50 \\
6 & Sintang & 1.500 & 1.500 & 965 & 550 \\
7 & Kapuas Hulu & 2.000 & 2.000 & 1.050 & 450 \\
8 & Kubu Raya & 16.905 & 16.905 & 12.290 & 1.750 \\
& Jumlah & & & 4.612 \\
\hline
\end{tabular}

Sumber : Dinas Pertanian Provinsi Kalimantan Barat. 2017

Dana yang disiapkan untuk perluasan sawah di wilayah Sumatera, Jawa, Kalimantan, Sulawesi dan Nusa Tenggara senilai Rp. 16.000.000/ha dan untuk wilayah Papua, Papua Barat, Maluku dan Maluku Utara senilai Rp. 19.000.000/ha. Pelaksanaan pekerjaan mempergunakan sistem/pola swakelola atau dengan pengertian pelaksana dapat melakukan sendiri pekerjaan yang telah diterimanya menurut spesifikasi pekerjaan yang telah disepakati. Dalam hal pelaksana (penerima pekerjaan) tidak dapat melaksanakan sendiri pekerjaan tertentu, seperti pekerjaan land clearing, land levelling, atau pembuatan saluran, maka pelaksana dapat melakukan kerjasama pekerjaan dengan mitra kerjanya (pihak lain), namun tanggungjawab kegiatan secara keseluruhan berada sepenuhnya di pihak pelaksana.

Pelaksanaan perluasan sawah di Provinsi Kalimantan Barat yaitu antara Dinas Pertanian Provinsi Kalimantan Barat dengan Kodam XII Tanjung Pura. Beberapa point penting dalam kerjasama ini antara lain: 
(i) Dinas Pertanian provinsi membiayai seluruh kegiatan dan pelaksanaannya di lapang adalah Kodam, (ii) beberapa kegiatan yang telah disepakati antara lain : menyiapkan kerangka acuan kerja, pembersihan/peralatan lahan (land clearing/leveling), pembuatan saluran tersier dan pengolahan lahan, (iii) waktu kerjasama dari bulan Januari sampai bulan Juni 2016.

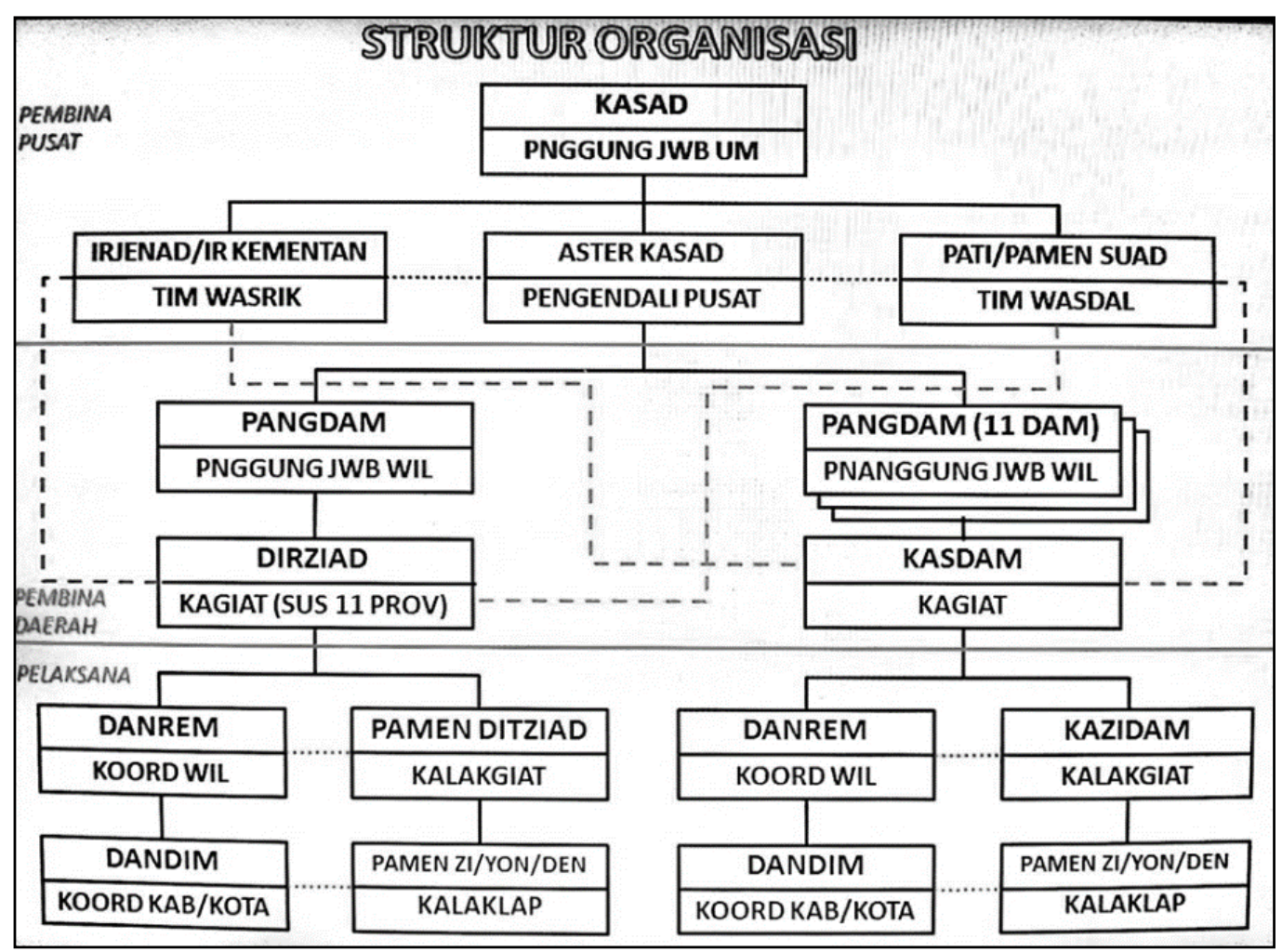

Gambar 1. Struktur organisasi TNI terkait dengan penyelenggaraan perluasan sawah

Adapun jenis kegiatan land clearing antara lain : menebang pohon yang tumbuh pada lahan, pengumpulan batang, cabang dan ranting yang sudah ditebang dan pembersihan lahan dari sisa-sisa hasil pembabatan, pemotongan, pencabutan akar dan sampah-sampah yang ada dilokasi. Sementara yang dimaksud dengan kegiatan land lavelling antara lain : penyisihan lapisan top soil (tanah pucuk), pengikisan, penggusuran dan penimbunan tanah untuk memperoleh lahan yang datar, pembuatan lahan berteras bangku apabila lokasi berada pada lahan miring, pemadatan lereng talud teras dengan tujuan pencegahan terjadinya erosi tanah pada lahan yang dicetak dan pengembalian lapisan top soil diatas permukaan lahan yang telah dicetak.

Prosedur Dan Pelaksanaan Kegiatan Perluasan Sawah. Prosedur atau mekanisme pembuatan kontrak kegiatan pencetakan sawah, dilakukan melalui penyusunan Survey Investigasi dan Desain (SI \& D) dan Pekerjaan Lapang. SI \& D merupakan salah satu kelengkapan dalam mencetak sawah dengan prosedur pelaksanaan dimulai dari : Identifikasi CPCL, Survei Investigasi, Penetapan Lokasi, Desain, Konstruksi (land clearing dan land levelling) dan bantuan saprotan untuk pemanfaatan lahan sawah baru (Direktorat Perluasan dan Perlindungan Lahan, 2016). Penyusunan SI \& D dan pelaksana dilakukan oleh pihak yang berbeda. SI \& D Provinsi Kalimantan Barat dilakukan oleh LPPM Universitas Tanjungpura, sedangkan pelaksana perluasan sawah dilakukan oleh IPL (Instansi Pemerintah Lain). Calon penerima dan calon lokasi (CPCL) disusun dan diusulkan oleh Dinas Pertanian Kabupaten ke Dinas Pertanian Provinsi untuk ditetapkan sebagai penerima manfaat. 
Lokasi yang dinyatakan layak untuk kegiatan perluasan sawah adalah : (i) jaringan irigasi/drainase sudah dibangun atau akan dibangun bersamaan dengan selesainya perluasan sawah kecuali sawah tadah hujan, (ii) cukup tersedia air, (iii) kondisi tanah sesuai untuk pertumbuhan padi, (iv) status dan batas kepemilikan tanah jelas, (v) petani ada dan berdomisili di desa lokasi atau berdekatan dengan lokasi, (vi) tersedianya prasarana penunjang dan kelengkapan lainnya. Khusus untuk lahan rawa seperti di Provinsi Kalimantan Barat, kriteria yang dipergunakan adalah : (i) lahan sesuai untuk tanaman padi sawah rawa pasang surut dan atau lebak, sudah ada petani dalam satu wadah kelompok, status petani jelas bisa pemilik atau penggarap, luas lahan pemilik penggarap maksimum $2 \mathrm{ha} / \mathrm{kk}$, petuas lapang sudah ada dan lokasi mudah diakses. (ii) di lahan tadah hujan kriterianya hampir sama, cuma ditambahkan mempunyai bulan basah > 3 bulan terutama yang tersedia air untuk 1 kali tanam.

SI dan D yang telah disusun tidak dapat dipergunakan, karena dalam pelaksanaan ditemukan beberapa hambatan yaitu: (i) kebijakan pemerintah daerah yang berubah sehingga terjadi perubahan atas calon lokasi yang ada di SI ; (ii) faktor alam pada saat pelaksanaan kegiatan (akses mobilisasi yang terputus) mengingat beberapa lokasi dalam vegetasi berat dan lahan yang masih bergambut dengan jenis tanah yang sangat poros ; (iii) adanya perubahan sosial masyarakat mengingat CPCL dilakukan 1 tahun sebelumnya, (iv) SI \& D disusun sebagai perencanaan pencetakan sawah baru dengan kondisi optimal, namun perbedaan vegetasi dan kondisi lapangan mengakibatkan dalam pelaksanaan fisiknya dapat terjadi beberapa perubahan yang tidak sesempurna seperti yang dipersyaratkan didalam SI dan D.

Pelaksanaan perluasan sawah di Kabupaten Sanggau dan Landak pada tahun anggaran 2016 tidak seluruhnya berdasarkan Survay Investigasi dan tidak ada sama sekali yang mempergunakan Desain cetak sawah. Beberapa alasan umumnya terjadi perubahan ini karena : (i) vegetasinya terlalu berat, (ii) lahan kelompok tani tidak dalam satu hamparan, (iii) berada didataran tinggi sehingga susah untuk diairi, (iv) tidak mendapat izin dari pemilik lahan karena lahannya masih ditanami tanaman produktif dan (v) lahan yang akan dicetak termasuk lahan yang tak boleh dicetak berdasarkan pedum seperti : lahan yang ada di hutan lindung, dll.

Sisi pelaksanan cetak sawah (Kodam) permasalahan yang dirasakan antara lain : (i) waktu pekerjaan yang sangat pendek hanya 6 bulan untuk mengerjakan 4.800 ha sawah baru di Kabupaten Sanggau dan 4.000 ha di Kabupaten Landak ; (ii) lokasi lahan dengan vegetasi tingkat kesulitan yang beragam ; (iii) sulitnya mobilisasi alat. Disisi lain menurut Dinas Pertanian provinsi beberapa manfaat melibatkan TNI dalam pelaksanaan cetak sawah antara lain : (i) LSM atau wartawan bodrek jarang atau tidak pernah lagi mendatangi dinas pertanian untuk bertanya tentang pelaksanaan cetak sawah, (ii) lebih gampang memobilisasi alat-alat berat ke lokasi cetak sawah, (iii) pendekatan ke tokoh masyarat/adat lebih mudah dan cepat.

Pelaksanaan Perluasan Sawah Dari Sisi Penerima. Ada beberapa respon dari masyarakat tentang adanya kegiatan perluasan sawah ini. Respon sangat baik, terutama pada lokasi yang petaninya berladang pindah. Dengan mendapatkan sawah, maka kegiatan menggarap lahan dengan cara membakar hutan akan berkurang. Respon masyarakat yang mendukung, terutama untuk petani yang sudah terbiasa menanam padi dan memahami betul tentang budidaya padi. Petani tersebut mengharapkan tidak hanya dapat sawah baru, tetapi pemerintah juga memberikan bantuan bibit dan pupuk. Respon yang kurang mendukung dirasakan bagi masyarakat yang masih rendah pemahaman tentang budidaya padi, bagi yang lokasi dekat dengan perkebunan masih mengutamakan kerja dikebun pada saat musim gadu dan hanya menanam padi pada musim rendeng

Ada beberapa alasan yang dikemukakan oleh petani kenapa mau ikut kegiatan perluasan sawah, yaitu: (i) lokasinya tidak jauh dari rumah petani (Tabel 3) ; (ii) ingin bertani padi karena beras merupakan kebutuhan pangan pokok; (iii) ingin meningkatkan pendapatan dan kesejahteraan petani; dan (iv) perubahan lahan non sawah menjadi sawah dapat meningkatkan harga jual dan nilai sewa lahan sawah 
(Tabel 4). Alasan tersebut didasari oleh kondisi lahan sebelum dicetak merupakan lahan kering datar yang hanya ditumbuhi oleh tanaman hutan seperti : kayu-kayuan, semak belukar dan kebun yang tidak tertata dengan baik.

Tabel 3. Lokasi Perluasan Sawah

\begin{tabular}{lllccc}
\hline No & Kabupaten & \multirow{2}{*}{ Kecamatan } & \multicolumn{3}{c}{ Jarak ke lokasi lahan $(\mathbf{k m})$} \\
\cline { 3 - 5 } & & & Kota Kab & Kota Kec & Rumah Petani \\
\hline 1 & Sanggau & Parindu & 60 & 30 & 2 \\
2 & & Tayan Hulu & 100 & 10 & 1 \\
3 & Landak & Mandor & 100 & 15 & 2 \\
4 & & Sengah Temila & 60 & 10 & 1 \\
\hline
\end{tabular}

Tabel 4. Kondisi Lahan Sebelum Perluasan

\begin{tabular}{llllll}
\hline No & Kabupaten & Kondisi dan Topografi & Status & $\begin{array}{c}\text { Pemanfaatan } \\
\text { Lahan Sebelumnya }\end{array}$ & Sumber Air \\
\hline 1 & Sanggau & Lahan kering datar & Milik & Semak belukar & Sungai, mata air, hujan \\
2 & Landak & Lahan kering datar & Milik & Kebun, kayu-kayuan & Sungai, mata air, hujan \\
\hline
\end{tabular}

Pekerjaan utama penerima manfaat cetak sawah sebelumnya paling banyak di tanaman pangan $(77,2 \%)$, perkebunan $(12,2 \%)$, hortikultura $(5 \%)$ dan buruh tani $(5,2 \%)$. Dengan latar belakang pekerjaan di pertanian, maka tak heran semangat untuk dapat lahan sawah menjadi tinggi. Semangat mendapatkan kegiatan cetak sawah terlihat dari partisipasi petani dimana ikut terlibat aktif dalam menentukan lokasi yang akan dijadikan lahan sawah. Di Kabupaten Sanggau semangat yang sangat tinggi juga dilakukan petani pada kegiatan meratakan tanah, membuat galengan, membuat jalan usahatani dan mengolah tanah (Tabel 5). Sebaliknya semangat atau pertisipasi untuk kegiatan tersebut di Kabupaten Landak tergolong rendah. Salah satu penyebab utamanya adalah kondisi lahan yang lebih berat, sehingga lebih mempercayakan kepada TNI untuk menyelesaikannya.

Tabel 5. Tingkat Partisipasi Petani Penerima Lahan Cetak Sawah

\begin{tabular}{crrrrrrrr}
\hline No & Kabupaten & Pembukaan & $\begin{array}{c}\text { Perataan } \\
\text { tanah }\end{array}$ & $\begin{array}{c}\text { Pembuatan } \\
\text { galengan }\end{array}$ & $\begin{array}{c}\text { Pembuatan } \\
\text { Salursan } \\
\text { Irigasi }\end{array}$ & $\begin{array}{c}\text { Pembuatan } \\
\text { Jalan } \\
\text { Usahatani }\end{array}$ & $\begin{array}{c}\text { Pengolahan } \\
\text { tanah }\end{array}$ & pengawasan \\
\hline 1. & Sanggau & Tinggi & Tinggi & Tinggi & Sedang & Tinggi & Tinggi & Sedang \\
2. & Landak & Tinggi & Rendah & Rendah & Rendah & Rendah & Sedang & Sedang \\
\hline
\end{tabular}

Dalam perluasan sawah baru ada beberapa permasalahan yang dirasakan oleh pelaksana dan penerima manfaat. Permasalahan itu antara lain : ada lahan yang dicetak tidak begitu luas,sehingga meningkatkan frekuensi mobilisasi alat. Sementara biaya untuk mobilisasi alat termasuk biaya yang mahal (Tabel 6). Bagi lahan yang sulit, terpaksa pelaksana tidak merealisasikannya dan mengganti dengan lokasi atau lahan lainnya. Setelah lahan tercetak menjadi sawah, pelaksana juga melakukan pengolahan tanah dengan satu kali pembajakan dan dua kali penggaruan. Seluruh petani responden penerima manfaat mengakui tidak ada biaya yang dikeluarkan dalam mengolah lahan sawah baru. 
Tabel 6. Perkembangan partisipasi petani di masing-masing lokasi contoh

\begin{tabular}{cccccccc}
\hline No & Kabupaten & $\begin{array}{c}\text { ada kegiatan } \\
\text { pemindahan } \\
\text { alat }\end{array}$ & $\begin{array}{c}\text { mobilisasi } \\
\text { menjadi } \\
\text { mahal }\end{array}$ & $\begin{array}{c}\text { ada lokasi } \\
\text { target yang } \\
\text { sangat sulit } \\
\text { dicetak }\end{array}$ & $\begin{array}{c}\text { Berapa kali } \\
\text { pengolahan } \\
\text { tanah, }\end{array}$ & $\begin{array}{c}\text { Berapa kali } \\
\text { penggaruan }\end{array}$ & $\begin{array}{c}\text { Dalam } \\
\text { pengolahan } \\
\text { tanah petani } \\
\text { dibayar }\end{array}$ \\
\hline 1. & Sanggau & Ya & Ya & Ya & 1 & 2 & Tidak \\
2. & Landak & Ya & Ya & Ya & 1 & 2 & Tidak
\end{tabular}

Manfaat Perluasan Sawah. Dari segi petani yang menerima perluasan sawah manfaat diantaranya : (i) petani sudah mulai mengurangi kebiasaan membuka lahan dengan cara membakar, (ii) mengenal teknologi budidaya padi, (iii) terbukanya jalan dari yang biasa dilalui motor sekarang bisa dilewati mobil, (iv) bertambahnya sumber penghasilan yang biasanya dari berladang atau berkebun (karet,sawit) sekarang bisa dari menjual hasil gabah/padi. Jadi tidak terlalu panik apabila harga sawit turun, (v) tidak kesulitan lagi mencari beras, (vi) petani sawit juga mendapat manfaat karena tanamannya mengalami penurunan serangan hama babi dan tikus, (vii) lahan petani yang sebelumnya ditanam padi gogo di lahan bekas rawa atau ladang sekarang kondisinya lebih bagus, karena lebih tertata, ada batasan yang jelas, menjadi lebih rata dan terbangun saluran air.

Dari Dinas Pertanian Kabupaten Sanggau manfaat adanya kegiatan perluasan sawah : (i) target produksi untuk kabupaten sudah tercapai. Hasil perdana perluasan sawah pada panen pertama bervariasi dari 0,5 ton gkp sd 1,5 ton gkp per hektar dan pada panen kedua meningkat antara 2,1 ton gkp sd 4,3 ton gkp per hektar. (ii) surplus beras, pada tahun 2015 seluruh kebutuhan beras dapat diperoleh dari petani lokal dan pada tahun 2016 persediaan beras mengalami surplus sebesar 90.000 ton. (iii) beberapa lahan marjinal yang tidak ditanami sekarang diusahakan atau lebih produktiv, (iv) meningkatkan IP dari satu kali setahun menjadi dua kali setahun. Untuk kondisi sekarang dari luas tanam 12.000 ha yang bisa ditanami dua kali setahun (IP 200) seluas 10.000 ha dan IP 100 seluas 4.200 ha.

\section{KESIMPULAN DAN SARAN}

Pencetakan sawah di Kabupaten Sanggau dan Landak sudah sesuai dengan tujuan kegiatan, yaitu : (i) realisasi perluasan sawah tahun 2016 sama dengan yang ditargetkan, (ii) petaninya ada, sawah yang dicetak lokasinya tidak jauh dari pemukiman petani yang menerima, (iii) sudah ditanami, 86 persen petani sudah menggarap lahannya, bahkan sudah ada yang menghasilkan dengan panen pertama antara 0,5 s/d 1 ton GKP/Ha. Lahan yang dicetak sebelumnya diusahakan untuk tanaman perkebunan dan kayu-kayuan.

Pencetakan sawah seharusnya mempergunakan hasil Survai Investigasi dan Desain, tetapi kenyataannya hasil survai investigasi dan desain yang dibuat oleh LPPM Universitas Tanjungpura tidak dapat dipergunakan secara optimal karena waktu perencanaan dan pelaksanaan kegiatan bersamaan waktunya. Kebijakan bermitra dengan TNI dalam melaksanakan perluasan sawah merupakan pilihan yang benar. Hal ini direpresentasikan dari waktu pelaksanaan yang sempit, hanya 6 bulan tetapi target dapat dicapai.

Anggaran Rp. 16.000.000 per hektar yang dijabarkan dalam RAB pada intinya tidak cukup. Hal ini disebabkan oleh biaya mobilisasi alat yang mahal dan tidak adanya biasa sosial. Umumnya biaya sosial dipergunakan untuk membuat jalan untuk mobilisasi alat, upacara adat sebelum membuka dan mencetak lahan. Untuk mengatasinya pemerintah perlu menaikkan biaya perluasan sawah perhektarnya.

Program perluasan sawah menjadi lebih baik kedepannya, maka disarankan : (i) perencanaan kegiatan dilaksanakan setahun sebelum pelaksanaan, (ii) diperlukan manajemen air dalam meningkatkan IP, (iii) dilanjutkan dengan kegiatan pertanian lainnya seperti: pelatihan budidaya, pemberian bantuan benih berlabel 
dan bermutu, subsidi pupuk dan alat-alat pertanian dan (iv) penerapan UU Perlindungan Lahan Pertanian dalam mencegah pengalihan fungsi lahan sawah baru.

\section{DAFTAR PUSTAKA}

Abdurahman A, Dariah A, dan M. A. (2008). Strategi dan Teknologi Pengelolaan Lahan Kering Mendukung Pengadaan Pangan Nasional. Jurnal Litbang Pertanian, 27(2). Retrieved from http://pustaka.litbang.pertanian.go.id/publikasi/p3272081.pdf

Agus, F., Irawan, I., Suganda, H., Wahyunto, W., Setiyanto, A., \& Kundarto, M. (2006). Environmental multifunctionality of Indonesian agriculture. Paddy and Water Environment, 4(4), 181-188. https://doi.org/10.1007/s10333-006-0047-5

Direktorat Perluasan dan Perlindungan Lahan. (2016). Pedoman Teknis Survei dan Investigasi Calon Petani Calon Lokasi dan Pemetaan Desain Perluasan Sawah. Jakarta: Kementerian Pertanian.

Irawan. B., G.S. Hardono, A. Purwoto, Supadi, V. Darwis. N. Sutrisno. dan B. Kartiwa. (2013). Studi Kebijakan Akselerasi Pertumbuhan Produksi Padi Di Luar Pulau Jawa (Tahun ke 2). Pusat Sosial Ekonomi Dan Kebijakan Pertanian.

Irawan, B. (2005). Konversi lahan sawah: potensi dampak, pola pemanfaatannya, dan faktor determinan dinas pekerjaan umum 2014. Forum Penelitian Agro Ekonomi, 23(1), 1-18.

Kompas. (2012). Pemerintah Abaikan Konversi. Lahan Tidak Menjadi Prioritas Produksi Pangan. In Kompas (Sabtu 14 J). Kompas.

Mulyani, A., \& Agus, F. (2006). Potensi Lahan Mendukung Revitalisasi Pertanian. Mulfifungsi Dan Revitalisasi

Pertanian., D. J. P. dan S. (n.d.). Pedoman Teknis Perluasan Sawah Pola Swakelola. Jakarta: Kementerian Pertanian.

Sulaiman. A .A. (2017). Peningkatan Produktivitas dan Daya Saing Komoditas Pertanian. Keynote Speech Pada Seminar Nasional Peningkatan Produktivitas Dan Daya Saing Komoditas Pertanian Fakultas Pertanian Universitas Galuh.

Sumaryanto, Friyatno, S., \& Irawan, B. (2005). Konversi Lahan Sawah ke Penggunaan Non Pertanian dan Dampak Negatifnya. Prosiding Seminar Nasional Multifungsi Lahan Sawah, 1-18.

Suparman.F. (2016). Sawah Beralih Fungsi. Retrieved from http://www.beritasatu.com/nasional/398530setiap-tahun-60000-ha-sawah-beralih-fungsi.html. 